УДК 621.91:621.396.6

DOI 10.36910/6775-2313-5352-2021-18-18

Prydalnyi B.I.

Lutsk National Technical University

\title{
MECHATRONIC CLAMPING MECHANISM WITH ELECTRO-HYDRAULIC ACTUATOR FOR MACHINE SPINDLE UNITS
}

The design of the clamping mechanism for fixing workpieces and tools in the spindle assemblies of machines that is equipped with an additional subsystem to provide the possibility of programmable settings to the required clamping force is presented. The electronic unit and electromechanical energy converters provide the possibility of reconfiguration by reprogramming the clamping mechanism according to the different tasks comparatively easily. The obtained results help to expand the functionality of clamping mechanisms, and consequently the functionality of machine tools and their technological flexibility.

Keywords: electro-hydraulic actuator, spindle unit, clamping chuck, transmission-amplifying mechanism, translational motor

Introduction and problem statement. There is a trend in the development of the new machines generation where an increasing number of functions are transferred from mechanical components to intelligent. This tendency forms the basis for the creation of new machine control systems and enhances the possibility usage of information technologies in technical spheres. Electronic and electromechanical units can be reprogrammed according to the different tasks comparatively easily [1]. This helps to expand the functionality of machine tools and their technological flexibility. Simultaneously with the development of technologies, components of machine tolls that run in different types of energy and have different physical nature, such as mechanical, electrical, electromechanical, electronic, information etc, are merging gradually into a single structure [2]. Devices like that are able to perform movements of executive-level elements (final control elements) autonomously without connection with an upper-level control system in a technological machine due to the implemented computing processors into their structures [3].

Mechanisms for fixing workpieces and tools in spindle assemblies of modern machines need possibilities of optimal adjustment in accordance with the machining requirements, as well as the possibility of effective readjustment for providing technological flexibility. In particular, it is an important task to clamp objects made of materials with unique characteristics, and with diameters and magnitudes of their deviations different from their nominal values, providing nominal characteristics of clamping. The use of electric energy converters instead of their mechanical functional analogues in the components of technological machines allows achieving a number of advantages associated with a wide range of control and adjustment. There are designs of clamping mechanisms for fixing workpieces and tools in the spindle assemblies of machines that are equipped with additional kinematic chains and systems to provide the effect of self-adjustment on the diameter of the object for clamping [4].

There are known devices for clamping workpieces, which are installed in the spindle assemblies of metalworking machines and provide stabilization of the clamping force, even when the deviations of workpieces diameter relative to their nominal size are increased. An example of such a device is the device for clamping a workpiece with the shape of a rod [5], containing the conical sleeve, levers that are kinematically connected to the movable sleeve, the disk and the nut mounted on the drawetube (drawbar in form of a tube). The clamping mechanism is equipped with spring-loaded wedges with chamfers at the ends and the cylinder with the conical flange at one end of the inner surface. On the disk and the nut radial inclined grooves are made, in which the wedges are installed. In addition, the cylinder is attached to the conical sleeve and its conical flange is designed to interact with the chamfers of wedges. The disadvantage of this device is its relatively low reliability when working in automatic mode and the complexity of the design. As a promising design should be noted clamping mechanism for workpieces and tools [6] with a translational motor. The motor stator is located on the machine body and includes several electromagnets that are able to interact with electromagnets on the motor armature by an electromagnetic field. The magnets ate powered by a generator. The rotor of the generator is attached to the spindle and its stator is mounted on the machine body. The clamping collet 
is located on the end of the spindle and has the possibility to interact with the armature of the motor through the drawtube.

One of the most advanced is the device for clamping tools and workpieces that is installed on spindle assembly of the machine tool [7] is known. The clamping mechanism contains a screw transmission and the collet chuck for tools or workpieces. The screw transmission includes the transmission nut which is connected to the rotor of the electromechanical system, placed coaxially with the spindle with the possibility of rotation and longitudinal movement in both directions. The transmission nut has the possibility of force interaction with small-diameter hydraulic plungers through the axial bearing. The small-diameter hydraulic plungers located in the distributing sleeve create fluid pressure in the closed hydraulic system. The fluid pressure acts on coaxially located outlet plungers of a larger diameter, transmitting forces to the spring-loaded movable conical sleeve of the collet chuck. The disadvantage of this mechanism is the complexity of the design, the relatively high complexity of the control process when working in automatic mode and the relatively low reliability of work in conditions of contamination of the working surfaces of its screw transmission.

The main objective of the study. The purpose of research is determined by the need to eliminate the shortcomings of existing mechanisms for clamping workpieces and tools. The presented designs of mechanisms have the following common disadvantages:

- energy consumption while workpieces or tools are retained in the clamped state during machining;

- the high possibility of fluctuations in the magnitude of the clamping force due to uncontrolled changes in the voltage in the supply network;

- uncontrolled release of workpieces or tools due to accidental power loss;

- relatively small magnitude of the clamping force, which can be achieved due to the step-bystep interaction of the magnetic elements of the stator and rotor under conditions of limiting the diametrical overall size of CM;

- low rigidity of fixing the workpieces due to the presence of an elastic connection of the magnetic interaction in the kinematic chains, which provides the retention of the clamping forces during machining.

The major goal of the next research is to develop the design of a clamping mechanism for fixation workpieces and tools on spindle assemblies with the purpose to increase the magnitude and stability of the clamping force, as well as the reliability, efficiency and possibility of adjustment of the clamping.

Results of work. The problem is solved due to the fact that the device for clamping the rod stack and cylindrical tools is equipped with transmission-amplifying mechanism. The element of wedging mechanism in the form of a ball has the possibility of simultaneous force interaction with the respective shaped surfaces of the armature of the motor, spindle and at least one plunger of small diameter located in the spindle. When the plunger of small diameter is moving a pressure of the working fluid in the closed hydraulic system is created and acts on at least one plunger with a larger diameter. The plunger of a larger diameter transmits the force to the spring-loaded movable conical sleeve of the collet chuck.

For solving the task the new design of the CM is developed. The device contains (Fig. 1, 2) electromagnets 3 placed on the surface of rotor 2 which is movable in the axial direction and mounted on spindle 1 . They have the possibility of electromagnetic interaction with electromagnets 5 mounted on stator 4. Electromagnets 5 is supplied by electricity through connectors 6 . Electromagnets 3 are powered by electricity from rotor 7 of the generator which is fixed on spindle 1 . Stator 8 of the generator is rigidly attached to machine body 9 and has the ability of powering through connectors 10 . Stator 4 is rigidly attached to machine body 9 and armature 2 has the possibility of force interaction with at least one element 11 of the wedge mechanism in the form of a ball. Ball 11 also has the possibility of simultaneous force interaction with spindle 1 and the shaped surface of at least one plunger of small diameter 12 located in spindle 1. Plunger of small diameter 12 has the ability to move axially and force interaction with spindle 1 through spring 13 and working fluid 14 of a hydraulic system, which is also equipped with at least one plunger of a large diameter 15. Large-diameter plunger 15 is axially displaced and forcefully interacts with the axially movable conical sleeve 16 . Sleeve 16 is also capable of simultaneous interaction with collet 17 that is rigidly attached to spindle 1 and holding object 18. 


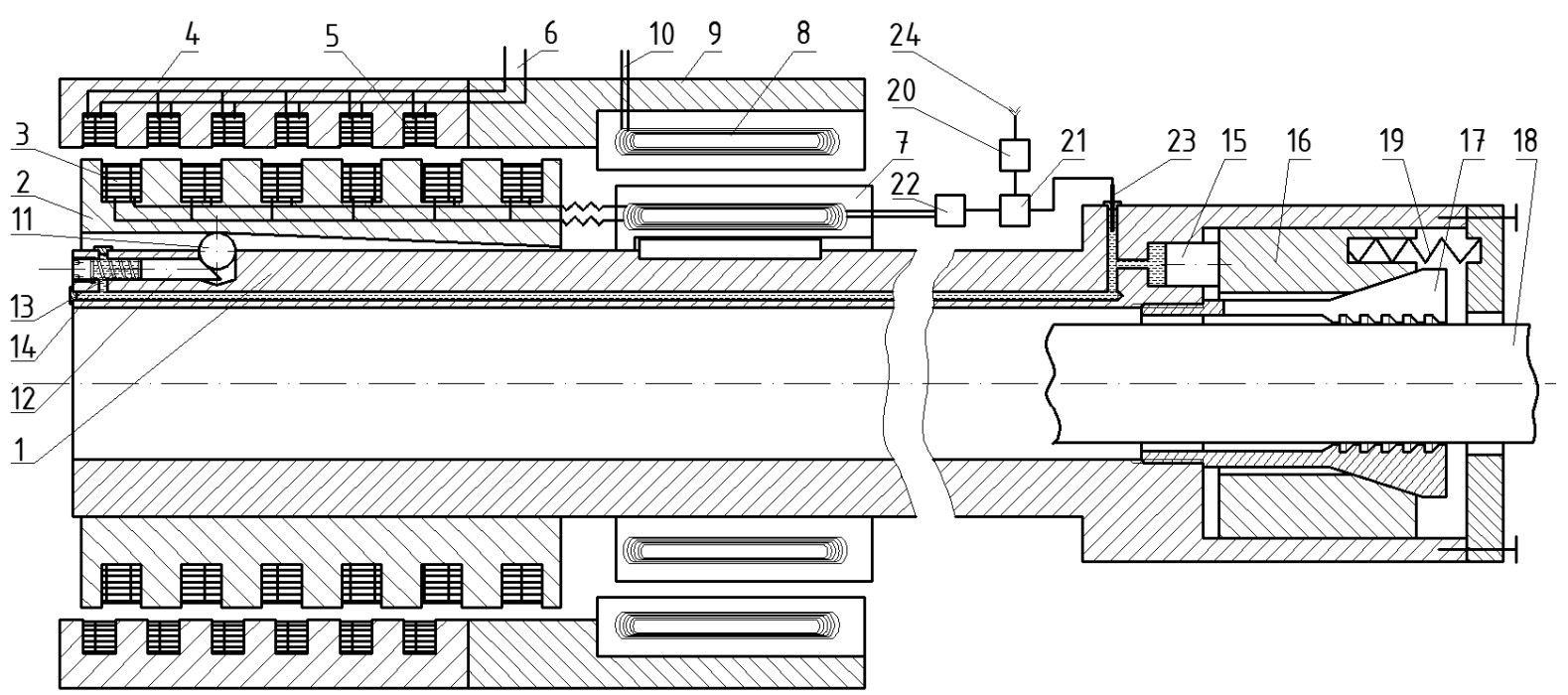

Figure 1- The mechatronic device with electro-hydraulic actuator for clamping objects in spindle units

The operation of the developed device for clamping cylindrical objects in the spindle assemblies of the machines is as follows. To clamp cylindrical object 18 (Fig. 1) electromagnets 5 are supplied alternately with current via connectors 6 . As the result, around electromagnets 5 an electromagnetic field is alternately formed that interacts with one of the nearest electromagnets 3 on armature 2. It causes the axial motion of armature 2. When current is applied to connectors 10 of the stator's windings 8 of the generator, there is a magnetic field under the action of which a current is generated in rotor 7 of the generator. The current from rotor 7 is supplied to electromagnets 3 . From electromagnets 3 axial force is transmitted to armature 2 and induce its axial movement relative to stator 4. Armature 2 is equipped with the shaped surface at an angle $\alpha$ (Fig. 1,2) to the axis of rotation. Due to the interaction of armature 2 with ball 11 there is its radial movement and force interaction of ball 11 with the shaped surface of plunger 12 . The interaction causes the axial movement of plunger 12, the deformation of spring 13 and, as a consequence, the movement of part of working fluid 14 through the channels of the closed hydraulic system into the chamber of plunger of the larger diameter 15. As a result, plunger 15 is pushed out of its working chamber and transmits force to conical sleeve 16 causing it to move and interact with the conical surface of collet 17. There is deformation of spring 19. The force interaction of sleeve 16 with collet 17 causes the convergence of its clamping jaws and clamping of object 18 . The magnitude of angle $\alpha$ is less than the friction angle in the contact of surfaces of ball 11 and armature 2. That fact allows preventing the movement of armature 2 relative spindle 1 under the force influence of ball 11 . This provides the self-braking effect in CM and, as a consequence, the sustained clamping state of object 18 without consuming electricity by electromagnets 3 and 5. The self-braking effect can also be used to increase the reliability of maintaining clamped state during machining with a significant reduction of energy consumption. The magnitude of the axial displacement of armature 2 depends on the actual diameter of object for fixation 18. The displacement stops when the required value of the clamping force is reached and the force opposing its axial displacement is increased to its maximum. The maximum magnitude of the clamping force of object 18 depends on the amount of current supplied to the electrical connectors 6 and 10 .

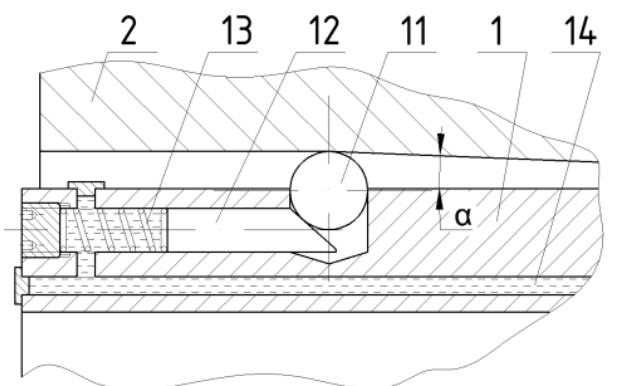

Figure 2- The wedging mechanism element and the plunger of the hydraulic system in the spindle 


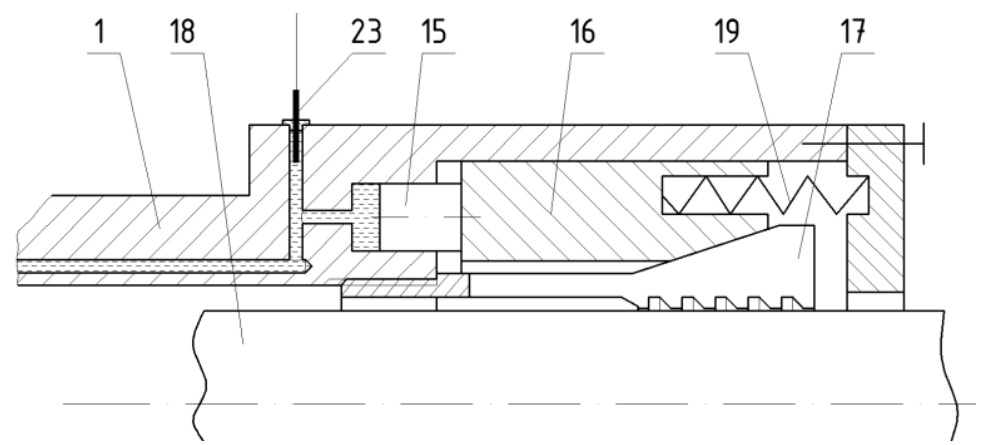

Figure 3- Fragment of the clamping chuck with drive plungers of the hydraulic system

The magnitude of the force for clamping object 18 is determined by the magnitude of the mechanical stress of the elements of the mechanism. It is reflected in the pressure of working fluid 14 in hydraulic system of the developed mechanism. Controlling the amount of clamping force makes it possible to avoid defects during machining, which may be the result of uncontrolled movements of the workpieces or tools under the action of cutting forces. Furthermore, it allows to avoid plastic deformations of workpieces made of comparatively soft or thin-walled materials. A control system where the signal about pressure in hydraulic system is used to determine the amount of clamping force is proposed.

The developed control system includes hydraulic pressure sensor 23 (Fig. 4) installed in the hydraulic system near the chamber of plunger of larger diameter 15 . Before the clamping process, the magnitude of the control signal $L_{i}$ from the control panel is transmitted to memory device 20 (Fig. 4) and recorded at its lower level. The control system also consists of data comparison device 21 and relay element 22 with a logic output. After the clamping process starts the value $L_{i}$ is rewritten at memory device 20 from its lower to the upper level and transmitted to comparison device 21, where it is compared with magnitude $L_{s}$ of hydraulic sensor 23. In comparison device 21 determines the result by using dependence $\Delta L_{c}=L_{s}-L_{i}$. The result of the calculation in comparison device $21 \Delta L_{c}$ is transmitted to relay element 22 with logical output and nonlinear static characteristic of the function of $\Delta L_{c}, L=f\left(\Delta L_{c}\right)$. Result $L$ takes discrete values 0 or 1 in cases where $\Delta L_{c}<\delta$ and $\Delta L_{c} \geq \delta$. The value $\delta$ is the minimum value of the signal at which relay control element 22 is triggered. The value of $\delta$ is set accordingly to the necessary magnitude of tolerance of the clamping force. This determines the operation of the $\mathrm{CM}$ control system in relation to the algorithm for switching on electromagnetic windings 3 and 5 (Fig. 1) of the electric drive CM. The clamping process is finished when the state of $\Delta L_{c}<\delta$ is reached.

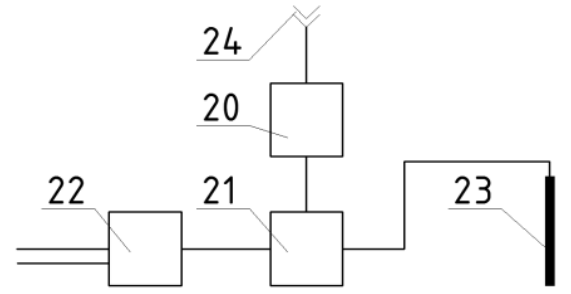

Figure 4- The structure of the control system unit

\section{Conclusions}

The developed construction of the new CM allows enhancing the characteristics of the clamping process of tools and workpieces in spindle units. In particular, the characteristic features of this design are that there is no energy consumption while the workpiece is retained in the clamped state during machining and the magnitude of the clamping force does not depend on uncontrolled changes in the voltage of a supply network. The new design ensures reliable holding of the workpiece even due to accidental loss of energy supply of CM. Due to the use of several energy converter mechanisms, a nominal amount of clamping force can be reached with small radial dimensions of the mechanism. The kinematical rigidity of transmission of mechanical energy is provided due to the absence of elastic elements and interactions in the closed kinematic chain. The energy supply of the CM is implemented by electromagnetic interaction between the stator and rotor. It gives the advantages such as the possibility to control the $\mathrm{CM}$ during spindle rotation. This also helps to reduce influences of 
mechanical disturbing effects on the stable operation of spindles. The developed clamping mechanism can be reconfigured by reprogramming according to the different tasks. The developed clamping mechanism can be reconfigured by reprogramming according to the needs of the value of clamping forces.

\title{
References
}

1.Alciatore D.G., Histand M.B. (2011). Introduction to Mechatronics and Measurement Systems. (Vol. 4). New York: Avenue of the Americas, NY 10020.

2.Bichop R.H. (2007). Mechatronic System, Sensors, and Actuators: Fundamentals and Modeling. (Vol 2). CRC Press.

3. Yonk Tak Hyan. Know-how feedback based on manufacturing features (STEP-NC Server)//Laboratory for Machine Tools and Production Engineering Aachen University of Technology. Aachen.2003. February 12.P.25.

4. Кузнєцов Ю. М., Придальний Б. І. Приводи затискних механізмів металообробних верстатів: монографія / Луцьк: Вежа-Друк, 2016. 352 с.

5.А. с. 917924 СССР, МПК В 23 В 13/00. Механизм зажима пруткового материала /Ю.Н. Кузнецов, И.И. Булах (СССР). - №2971408/25-08 ; заявл. 08.08.80 ; опубл. 07.04.82, Бюл. № 13.

6.Пат. 95863 Україна, МПК (2015.01) В23В 13/00. Пристрій для затиску пруткового матеріалу / Придальний Б.I, Усін В.I. заявник і власник патенту Луцький національний технічний університет. - №u201407939; заявл. 14.07.2014; опубл. 12.01.2015, Бюл. № 1.

7.Пат. 79495 Україна, МПК (2013.01) В23В 17/00, В23В 19/00, В23Q 3/00. Шпиндельний вузол верстата / Кузнєцов Ю.М., Придальний Б.І., Герра Ж. А. Хамуйєла (AG), Недобой В.А.; заявник i власник патенту Національний технічний університет України "Київський політехнічний інститут”. - №u201211892; заявл. 15.10.2012; опубл. 25.04.2013, Бюл. № 8/2013.

\section{Придальний Б.I.}

Луцький національний технічний університет

\section{МЕХАТРОННИЙ ЗАТИСКНИЙ МЕХАНІЗМ 3 ЕЛЕКТРОГІДРАВЛІЧНИМ ПРИВОДОМ ДЛЯ ШПИНДЕЛЬНИХ ВУЗЛІВ ВЕРСТАТІВ}

\begin{abstract}
Представлена конструкиія затискного механізму для закріплення заготовок та інструментів у шпиндельних вузлах верстатів, який оснащений додатковою підсистемою для забезпечення можливості програмного налаштування необхідної сили затиску. Електронний блок та електромеханічні перетворювачі енергії забезпечують можливість більш легкого пере налаштування механізму шляхом перепрограмування відповідно до заданих потреб обробки. Отримані результати допомагають розширити функиіональність затискних механізмів, а отже, функиіональність верстатів та їх технологічну гнучкість.

Ключові слова: електрогідравлічний привод, шпиндельний вузол, затискна ияанга, передавально-підсилювальні механізми, двигун поступальної дії.

Прыдальный Б.И.

Луцкий национальный технический университет

\section{МЕХАТРОННЫЙ ЗАЖИМНОЙ МЕХАНИЗМ С ЭЛЕКТРОГИДРАВЛИЧЕСКИМ ПРИВОДОМ ДЛЯ ШПИНДЕЛЬНЫХ УЗЛОВ СТАНКОВ}

Представленная конструкция зажимного механизма для закрепления заготовок $u$ инструментов в шпиндельных узлах станков, который оснащен дополнительной подсистемой для обеспечения возможности программного настройки необходимой силь зажима. Электронный блок и электромеханические преобразователи энергии обеспечивают возможность более легкого пере настройки механизма путем перепрограммирования в соответствии с заданными потребностей обработки. Полученные результаты помогают расширить функииональность зажимных механизмов, а следовательно, функииональность станков и их технологическую гибкость.

Ключевые слова: электрогидравлический привод, шпиндельный узел, зажимная ианга, передаточно-усилительные механизмы, двигатель поступательного действия . 